\title{
Distribution and abundance of aquatic plants of Oyan Lake, Ogun State, Nigeria
}

\author{
HENRY EYINA DIENYE", OLANIYI ALABA OLOPADE \\ Department of Fisheries, Faculty of Agriculture, University of Portharcourt, Choba P.M.B.5323, Rivers State, Nigeria. Tel.: +234-8036809439, \\ "email: henrydienye@gmail.com
}

Manuscript received: 6 November 2016. Revision accepted: 27 June 2017.

\begin{abstract}
Dienye HE, Olopade OA, 2017. Distribution and abundance of aquatic plants of Oyan Lake, Ogun State, Nigeria. Bonorowo Wetlands 7: 11-15. The distribution and abundance of aquatic plants from Oyan Lake were assessed bi-monthly between October 2012 and January 2013. In total, 20 species of aquatic plants were recorded, representing 13 families. Cyperaceae and Poaceae families had the highest species with four species each. A further study showed that Azolla africana had the highest abundance (richness), followed by Salvinia nymphellula, while the species with the lowest abundance (richness) was Ceratophyllum demersum. Ludwigia decurrens and Rhynchospora corymbosa had the lowest evenness (distribution), followed by Nymphaea lotus. Fimbristylis ferruginea had the highest evenness, followed by Echinochloa stagnina. The three most prominent species found at the Stations in order of prominence were: Azolla africana, Salvinia nymphellula, and Polygonum lanigerum occupying $42.33 \%$ of the area covered by aquatic plants. The biotic indices of species richness, Shannon - Wiener information function, evenness, and Simpson's Dominance were fairly distributed in the study area.
\end{abstract}

Keywords: Aquatic plants, distribution, classification, distribution, Oyan Lake

\section{INTRODUCTION}

Macrophytes are important components of the freshwater (aquatic) ecosystem because they enhance habitats' biological complexity and physical structure, increasing biodiversity within the littoral zones (Esteves 1998; Wetzel 2001; Pelicice et al. 2008). In addition, both live and dead materials (detritus) from aquatic macrophytes may serve as food resources for aquatic and terrestrial organisms (Lope et al., 2007). Macrophytes play a significant role in the hydro ecosystem by providing a breeding substrate for organisms, including fish, aquatic insects, and zooplankton. Many of them serve as food for fish (Ratusshnyale 2008). However, in most rivers and lakes, the excessive growth of macrophytes may provoke some negative effects (Bini et al. 2005), and it develops into an explosively large population only when the environment is altered

Nigerian inland water bodies serve as an important refuge for numerous animals and vascular plants that have sustained their communities. But in recent times, both natural and human-induced environmental problems have either destroyed or altered the associated ecosystem with consequent impact on the endowed natural resources. And yet little is presently known about Nigerian inland water bodies associated with flora and fauna, including their inventories, socio-economic values, and overall management (Daddy et al. 1993).

Among the least understood and least studied components of urban streams and rivers biota are aquatic macrophytes. This is rather unfortunate since changes in macrophytes communities may be especially indicative of major categories of urban stress. The health and structure of macrophytes communities are likely to be important determinants of water quality (Gregg and Rose 1982; Suren 2000; Balanson et al. 2005). There is very little information on aquatic plants, particularly the freshwater ecosystem. In this present study, an attempt has been made to analyze the pattern of species diversity and distribution of the aquatic macrophytes of the Oyan Lake, Ogun State, Nigeria.

\section{MATERIALS AND METHODS}

\section{Description of the Study area}

Oyan Lake is situated at about $26 \mathrm{~km}$ North-West of Abeokuta, Ogun State, Nigeria (Figure 1) that lies on latitudes between $7^{0} 15^{1}$ and $7^{0} 25^{1}$ and longitude $3^{0} 5^{1}$ and $3^{0} 15^{1}$. It is a gated spillway lake and covers an area of $40 \mathrm{~km}^{2}$ with a normal reservoir capacity of 140 million $\mathrm{m}^{3}$. The Lake was constructed on the Oyan River, a significant tributary to Ogun River with a catchment area of $9,000 \mathrm{~km}^{2}$; it is an artificial lake in Ogun State. It is the second-largest lake in the southern part of Nigeria (Adekoya 1991).

The lake has a tributary where the water flows in from the Oyan River and meets with the Ofiki River; the Hausas are predominantly the inhabitants of Ofiki while the Ilajes dominate the Oyan River. The climate of the study area is warm and humid. Two distinct seasons are felt during the year: rainy (March-October) and dry (NovemberFebruary). The range of rainfall was between $1600 \mathrm{~mm}$ and $2900 \mathrm{~mm}$ to provide all-year-round pictures of the aquatic plants of the study area. 


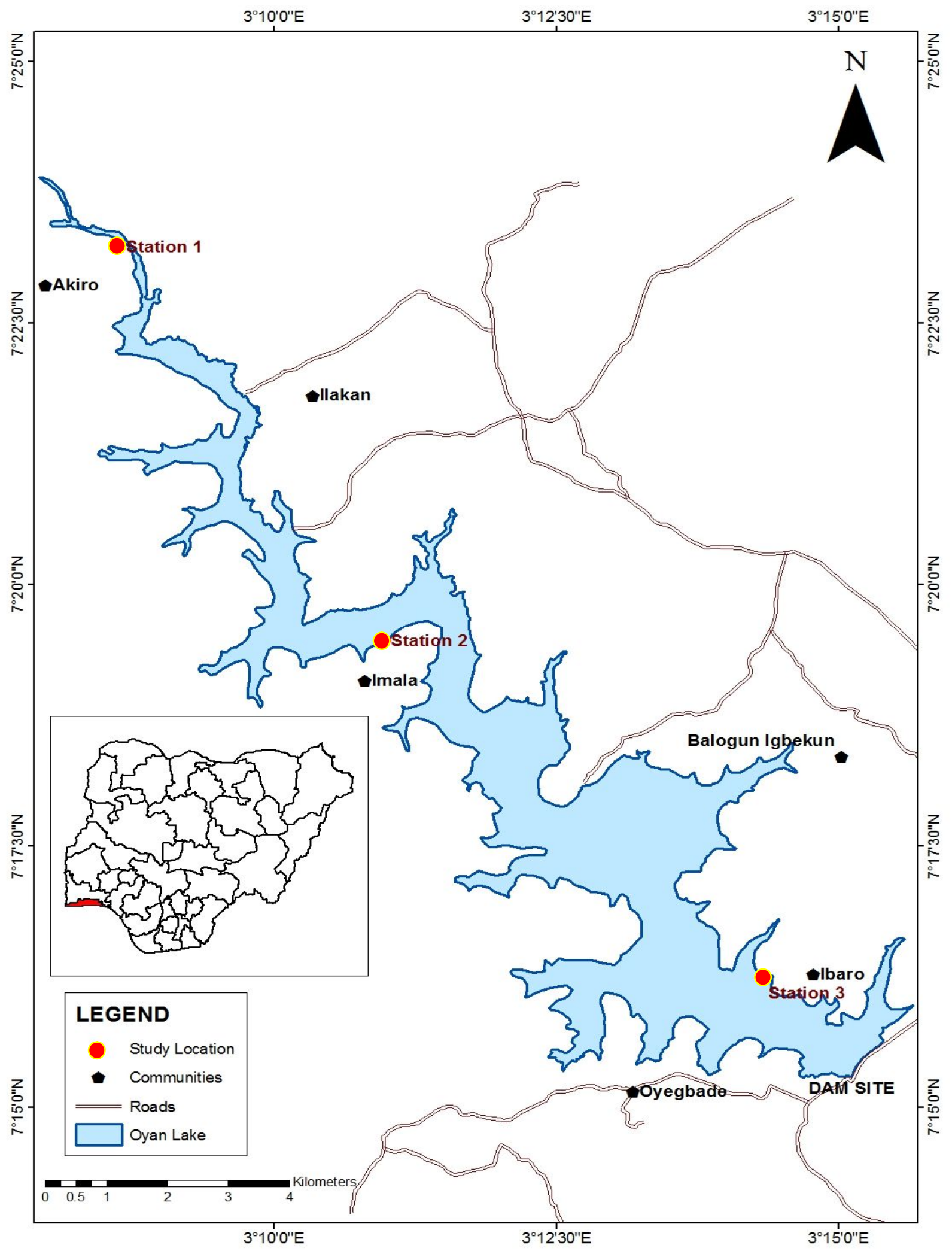

Figure 1. Study area showing the different sampling Stations in Oyan Dam, Ogun State, Nigeria 
Table 1. Morphometry of Oyan Dam, Ogun State, Nigeria (Adekoya 1991)

\begin{tabular}{ll}
\hline Morphometry & \\
\hline $\begin{array}{l}\text { Dam } \\
\text { Length of the crest }\end{array}$ & $1.1 \mathrm{~km}$ \\
Maximum height of the crest & $32.5 \mathrm{~m}$ \\
1st service spillway capacity & $2271 \mathrm{~m} 3$ per second \\
2nd Service spillway capacity & $3340 \mathrm{~m} 3$ per second \\
& \\
Reservoir & $27 \mathrm{~km}$ \\
Length & $6 \mathrm{~km}$ \\
Maximum width & $270 \mathrm{million}$ cubic meters \\
Water storage capacity & $40 \mathrm{~km} 2$ \\
Surface area & \\
& \\
\hline
\end{tabular}

\section{Collection of samples}

The study was conducted on Oyan Lake from October 2012 to January 2013, and sampling was done twice a month. A general survey of the Oyan Lake was made at three different study sites (Inlet of the Lake, Centre of the Lake, and dam site). In each field visit, aquatic plants from each of the three studies were collected following a standard approach (Janauer, 2003). Aquatic plants found at the edge of the Lake were easily collected, while the ones in the lake were collected with a paddled boat to the different zones through the assistance of a fisherman. A wooden square quadrat of $1 \mathrm{~m}^{2}$ was placed on the vegetation at random bearings at each zone, and counting was also carried out per square meter. These samples were respectively tagged for ease in identification following Akobundu and Agyakwa (1987).

\section{Data analysis}

The data generated were statistically analyzed using means and some ecological indices. These were:

Shannon-Weiner diversity index $\left(\mathrm{H}^{1}\right)=-\mathrm{E}[(\mathrm{ni} / \mathrm{N}) \times \mathrm{In}$ $(\mathrm{ni} / \mathrm{N})]$ (Shannon and Weaver 1963)

Where:

$\mathrm{H}^{1}=$ Diversity index, ni=the total number of individuals belonging to the ith species=total number of individuals for the site, and $\ln =$ the natural $\log$ of the number.

Simpson diversity $(1-\Delta)=1-\mathrm{E} n(\mathrm{n}-1) / \mathrm{N}(\mathrm{N}-1)$

Where:

$\mathrm{N}=$ the total number of organisms of all species, and $\mathrm{n}=$ the total number of organisms of a particular species

Margalef-value is the measure of species richness. It is expressed as

$\mathrm{d}=\mathrm{S}-1 / \ln \mathrm{N}$,

Where: $\mathrm{d}=$ Margalef value, $\mathrm{S}=$ number of species collected in a sample, and $\mathrm{N}=$ total number of individuals in the sample.

\section{Menhinicks Index (D) $=\mathrm{S} / \sqrt{\mathrm{N}}$}

Where:

$\mathrm{S}=$ Number of species in a population and $\mathrm{N}=$ Total number of individuals in $\mathrm{S}$ species

Pielou index measures how evenly the species are distributed in a sample community. It is expressed as:

$\mathrm{J}=1 / \mathrm{Hmax}$ (Pielou 1969)

Where:

$\mathrm{J}=$ Diversity evenness or Equitability Index. $\mathrm{H} 1=$ calculated Shannon-Weiner diversity index. (ShannonWeiner) Hmax+inS $\mathrm{S}=$ total number of species in a population in $=$ natural $\log$ of the number

Simpson dominance index $(\mathrm{C})=\Sigma(\mathrm{n} / \mathrm{N}) 2$ (Ogbeibu 2005)

Where:

$\mathrm{N}=$ the number of species in the ith species and $\mathrm{N}=$ total number of individuals.

\section{RESULTS AND DISCUSSION}

The samples collected during the survey were classified into 20 aquatic macrophytes species representing 13 families. Cyperaceae and Poaceae families had the highest species of four each, followed by Mimosaceae with two species. At the same time, the other ten families recorded one species each, respectively, as shown in Table 1. Bini et al. (1999) reported that Poaceae and Cyperaceae are among the best-represented families and the most important families in other freshwater ecosystems. Daddy et al. (1993) reported that in the herbarium of Kainji and Jebba Lake, 13 different aquatic plants families constituted thirtyone species. Family Poaceae ranked the commonest with fourteen species, representing another family. Ikenweiwe (2005) also classified macrophytes of Oyan Lake into 10 Families and 9 species, respectively. Family Poaceae and Cyperaceae ranked the commonest with 2 species each. In comparison, other families were represented by 1 species each Dienye (2015) classified macrophytes of the New Calabar River into ten families made up of 12 different species. The resulting family Cyperaceae recorded the highest number of species with 3 species, while the other nine families recorded one species each. According to Obot (1987), in the classification of aquatic plants of Nigeria, the family Poaceae has the highest number of species of 12 , according to the results of this study.

The species samples were zoned into floating, submerged, and emergent groups. Table 2 shows that 15 out of twenty identified species were grouped as emergent, two as submerged, and the remaining three as floating aquatic plants. Obot and Ayeni (1987) grouped aquatic plants of Kainji Lake, marginal flora species (31), 
submerged species (15), and floating and marginal species (4). Dienye (2015) reported that the zonation of the different species of macrophytes in the New Calabar River into floating, submerged and emergent. Among the 12 species samples, 10 were grouped as emergent, 2 as floating, and none were grouped as submerged during the sampling period. This finding shows that emergent species ranked the highest in the zonation of macrophytes, which is in line with this result.

The evenness is the distribution of species sampled among species in the community. Fimbristylis ferruginea had the highest distribution, followed by Echinochloa stagnina, while Ludwiga decurrens recorded the lowest distribution. In the study of the ecology of macrophytes of Jebba Lake carried out by Adesina et al. (1993), Vossia cuspidata has the highest calculated value while Ceratophyllum demersum, Tephrosia bracteolata, Nymphaea lotus, and Setaria pumila had the lowest in distribution.

The richness is the number of species present in a community Table 3 shows the abundance in each zone and the mean abundance of the community. The species Azolla africana had the highest richness, followed by Echinochloa stagnina and Oryza longistaminata with the same level of richness. Ceratophyllum demersum recorded the lowest richness among the species sampled in the community.

The similarity index shows the similarity between the different zones,i.e., the presence and absence of other species in each Station. The comparison of the stations and the respective percentages are shown in Table 4. The Stations compared, which has the highest percentage of $73.68 \%$, had the highest similarity of all the sampled stations, i.e., Station 2 and 3, followed by Station 1 and 3 with $31.58 \%$, with the slightest similarity.

Table 1. Checklist of aquatic plants species in Oyan Lake, Ogun State, Nigeria

\begin{tabular}{|c|c|c|}
\hline Family & Species & Common name \\
\hline Cyperaceae & $\begin{array}{l}\text { Rynchospora corymbosa } \\
\text { Mariscus longibracteatus } \\
\text { Cyperus esculentus } \\
\text { Fimbristylis ferruginea }\end{array}$ & Yellow Nutsedge \\
\hline Poaceae & $\begin{array}{l}\text { Echinochloa pyramidalis } \\
\text { Echinochloa stagnina } \\
\text { Sacciolepsis africana } \\
\text { Oryza longistaminata }\end{array}$ & Wild rice \\
\hline Onagraceae & Ludwigia decurrens & Water primrose \\
\hline Araceae & Pistia stratiotes & Water lettuce \\
\hline Polygonaceae & Polygonium lanigerum & Smartweed \\
\hline Curcubitaceae & Luffa aegyptiaca & Loofah, Loofah gourd \\
\hline Azollaceae & Azolla africana & Water velvet \\
\hline Hydrophyllaceae & Hydrolea glabra & \\
\hline Mimosaceae & $\begin{array}{l}\text { Mimosa pigra } \\
\text { Neptunia oleracea }\end{array}$ & Giant sensitive plant \\
\hline Salviniaceae & Salvina nymphellula & Salvinia \\
\hline Convolvulaceae & Ipomea triloba & \\
\hline Nymphaeaceae & Nymphaea lotus & \\
\hline Ceratophyllaceae & Ceratophyllum demersum & Water lily \\
\hline
\end{tabular}

Table 2. Zonation of aquatic plants in Oyan Lake, Ogun State, Nigeria

\begin{tabular}{|c|c|c|c|}
\hline Species & 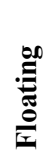 & 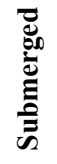 & 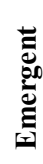 \\
\hline Ludwigia decurrens & & & + \\
\hline Pistia stratiotes & + & & \\
\hline Polygonium lanigerum & & + & \\
\hline Echinochloa pyramidalis & & & + \\
\hline Neptunia oleracea & & & \\
\hline Rynchospora corymbosa & & & + \\
\hline Echinochloa stagnina & & & + \\
\hline Oryza longistaminata & & & + \\
\hline Luffa aegyptiaca & & & + \\
\hline Azolla africana & + & & \\
\hline Fimbristylis ferruginea & & & + \\
\hline Mariscus longibracteatus & & & + \\
\hline Cyperus esculentus & & & + \\
\hline Hydrolea glabra & & & + \\
\hline Sacciolepsis africana & & & + \\
\hline Mimosa pigra & & & + \\
\hline Salvina nymphellula & + & & \\
\hline Ipomea triloba & & & + \\
\hline Nymphaea lotus & & & + \\
\hline Ceratophyllum demersum & & + & \\
\hline
\end{tabular}

Table 3. Distribution of aquatic plants in Oyan Lake, Ogun State, Nigeria

\begin{tabular}{|c|c|c|c|c|c|}
\hline Species & $\frac{0}{2}$ & 丞 & ڤ્) & $\stackrel{\pi}{0}$ & 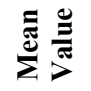 \\
\hline Ludwigia decurrens & 0.06 & 0.12 & 0.11 & 0.29 & 0.10 \\
\hline Pistia stratiotes & 0.05 & 0.10 & 0.09 & 0.24 & 0.08 \\
\hline Polygonium lanigerum & 0.03 & 0.06 & 0.06 & 0.15 & 0.05 \\
\hline Echinochloa pyramidalis & 0.05 & 0.09 & 0.08 & 0.22 & 0.07 \\
\hline Neptunia oleracea & 0.08 & 0.14 & 0.14 & 0.36 & 0.13 \\
\hline Rynchospora corymbosa & 0.08 & 0.14 & 0.14 & 0.36 & 0.12 \\
\hline Echinochloa stagnina & 0.03 & 0.06 & 0.06 & 0.15 & $0.05^{* * *}$ \\
\hline Oryza longistaminata & 0.03 & 0.07 & 0.06 & 0.16 & $0.05^{* * *}$ \\
\hline Luffa aegyptiaca & 0.06 & 0.12 & 0.11 & 0.29 & 0.10 \\
\hline Azolla africana & 0.02 & 0.04 & 0.04 & 0.10 & $0.03 * *$ \\
\hline Fimbristlysis ferruginea & 0.06 & 0.11 & 0.11 & 0.28 & 0.09 \\
\hline Mariscus longibracteatus & 0.08 & 0.15 & 0.14 & 0.37 & 0.12 \\
\hline Cyperus esculentus & 0.08 & 0.15 & 0.14 & 0.37 & 0.12 \\
\hline Hydrolea glabra & 0.06 & 0.11 & 0.10 & 0.27 & 0.09 \\
\hline Sacciolepsis africana & 0.05 & 0.09 & 0.09 & 0.23 & 0.08 \\
\hline Mimosa pigra & 0.05 & 0.10 & 0.09 & 0.24 & 0.08 \\
\hline Salvina nymphellula & 0.03 & 0.06 & 0.05 & 0.14 & 0.05 \\
\hline Ipomea triloba & 0.05 & 0.10 & 0.09 & 0.24 & 0.08 \\
\hline Nymphea lotus & 0.05 & 0.09 & 0.08 & 0.22 & 0.07 \\
\hline Ceratophyllum demersum & 0.10 & 0.18 & 0.17 & 0.45 & $0.15^{*}$ \\
\hline
\end{tabular}

Note: *Highest, ** Lowest, *** Same calculated mean value

Table 4. Percentage of similarity index between species of different stations in Oyan Lake, Ogun State, Nigeria

\begin{tabular}{llll}
\hline Station & $\mathbf{1}$ and $\mathbf{2}$ & $\mathbf{1}$ and $\mathbf{3}$ & $\mathbf{2}$ and $\mathbf{3}$ \\
\hline Percentage & 36.84 & 31.58 & 73.6 \\
\hline
\end{tabular}


EVENESS

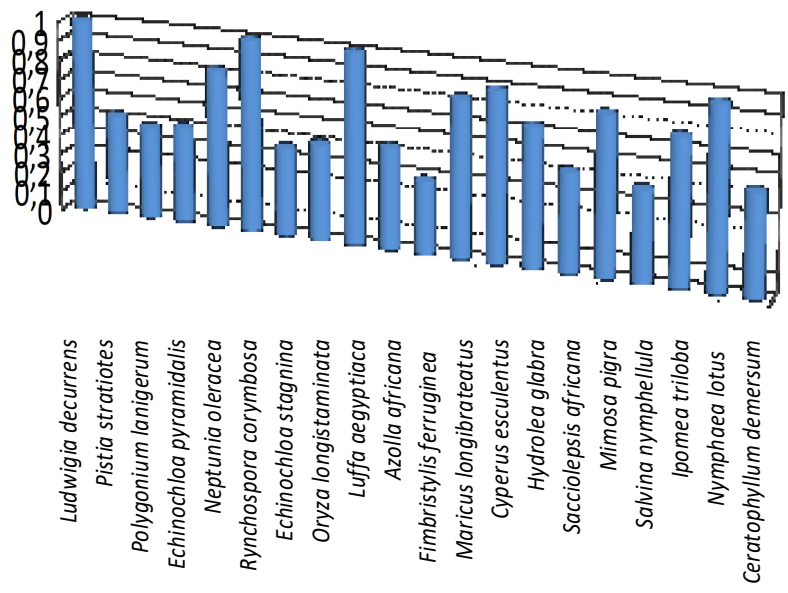

Figure 2. The evenness (distribution) of aquatic plants of Oyan Lake, Ogun State, Nigeria

In conclusion, the aquatic plants of Oyan Lake constitute different species with different families. A total of 20 species of aquatic plants representing 13 families were encountered; the family Cyperaceae and Poaceae had the highest species. Azolla africana dominated the area and is evenly distributed. The species is of high economic importance, while Ceratophyllum demersum, a submerged plant, was the least species in the study area. From most research carried out on aquatic plants of Lakes and dams, it has been observed that the families Cyperaceae and Poaceae dominated the water body with the highest corresponding species.

\section{REFERENCES}

Adekoya BB. 1991. A diagnostic survey of small-scale captures and culture fisheries in Ogun State. OGADEP Abeokuta.

Adesina GO, Daddy F, Aina E. 1993. Studies of the ecology of aquatic macrophytes and association littoral vegetation of Jebba Lake. In: NIFFR Annual Report, Nigeria.

Akobundu IO, Agyakwa CW. 1987. A Handbook of West African Weeds. International Institute of Tropical Agriculture, Ibadan.

Balanson PC, Mac MJ, Smith SB. 2005. Challenges in the development and use of ecological indicators. Ecol Ind 1 (1): 3-10. DOI: 10.1016/S1470-160X(01)00003-6.

Bini LM, Oliveria LG, Souza DC, Carvalho P, Pinto MP. 2005. Patterns of the aquatic macrophytes cover in Cachoeira Dourada Reservoir. Braz J Biol 65 (1): 19-24. DOI: 10.1590/S1519-69842005000100004.

Daddy F, Adesina GO, Bankole NO, Isah U, Owotunse S. 1993. Flora and Fauna Resources are Associated with Kainji, Jebba, Shriroro, and Wuya Water Bodies. NIFFR Annual Report, Nigeria

Dienye HE. 2015. Species diversity of macrophytes of the New Calabar River Niger Delta Nigeria. Intl J Fish Aquat Stud 3 (1): 409-413.
PERCENTAGE RICHNESS

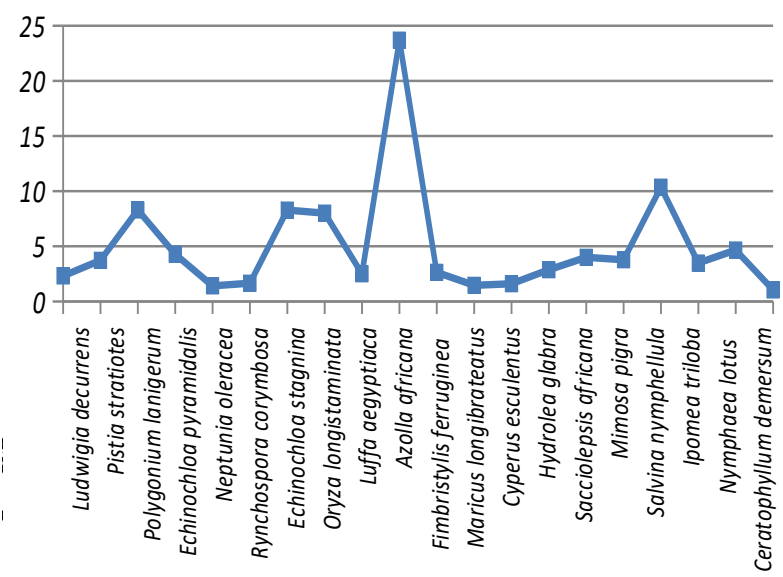

Figure 3. The percentage richness (abundance) of aquatic plants of Oyan Lake, Ogun State, Nigeria

Esteves FA. 1998. Fundamentos de Limnologia. Interciencia, Rio de Janeiro, Brazil. [Portuguese]

Gregg WW, Rose FL. 1982. The effects of aquatic macrophytes on the stream microenvironment. Aquat Bot 14: 309-324. DOI: 10.1016/0304-3770(82)90105-X.

Ikenweiwe NB. 2005 Limnology and Plankton Abundance in Relation to Fish Production in Oyan Lake South-Western Nigeria. [Dissertation]. University of Agriculture, Abeokuta, Nigeria.

Janauer GA. 2003. Methods. Archiv fur Hydrobiologie 14 (1-2, Suppl. 147): 9-16. DOI: $10.1127 / / r / 14 / 2003 / 9$.

Lopes CA, Benedito-Cecilio E, Martinelli LA. 2007. Variability in the carbon isotope signature of Prochilodus lineatus (Prochilodontidae, Characiformes), a bottom-feeding fish of the Neotropical region. J Fish Biol 70 (6): 1649-1659. DOI: 10.1111/j.10958649.2007.01388.x.

Obot EA, Ayeni JSO. 1987. A Handbook of Common Aquatic Plants of the Kainji Lake Basin, Nigeria. Kainji Lake Research Institute/ Saolog Printing Production, Ilorin, Nigeria.

Ogbeibu AE. 2005. Biostatistics: A Practical Approach to Research and Data Handling. Mindex Publishing Company Limited, Benin City, Nigeria.

Pelicice FM, Thomas SM, Agostinhno AA. 2008. Simple relationships to predict attributes of fish assemblages in patches of submerged macrophytes. Neotrop Ichthyol 6 (4): 543-550. DOI: 10.1590/S167962252008000400001

Pielou EC. 1969. An Introduction to Mathematical Ecology. John Wiley \& Sons, New York.

Ratusshnyale AA. 2008 The role of aquatic macrophytes in hydroecosystem of the Kuibysheu Reservoir. J Agric Environ Sci 4 (1): $1-8$.

Shannon CE, Weaver E. 1963. The mathematical theory of communication. The University of Illinois, Urban Press Illinois.

Suren L. 2000 Urban drainage impacts a receiving waters quality water. Sci Tech 27: 151-158.

Wetzel RG. 2001. Limnology: Lake and River Ecosystems. Academic, San Diego, California, USA. 